\title{
RESOURCES OF ATTITUDES IN STUDENTS' TOURISM BLOGS
}

\author{
Ni Putu Era Marsakawati, Rima Andriani Sari, Putu Dewi Merlyna Yuda \\ Pramesti, Komang Windi Wahana Putra \\ Universitas Pendidikan Ganesha, Singaraja, Indonesia \\ E-mail:marsakawatiera@gmail.com
}

Received: 2021-05-19

Accepted: 2021-06-07

\begin{abstract}
Studies concerning the use of attitude resources in students' writing have been conducted by researchers. However, limited attention has been given to investigate how resources of attitude are used in a hybrid genre, such as blog. This paper aims at reporting how attitude resources are realized in students' tourism blogs. 10 tourism blogs written by the seventh-semester students of English Education Department, taking English for Tourism course were purposively selected as the source of data. These data were chosen because their topics were about tourist attractions in Bali. The data were analyzed by following appraisal language analysis theory. The results show that appreciation and affect resources were used by the students in their blogs. However, the resources used by the students were basic and repetitive words. This study suggests English instructors provide explicit teaching of attitudinal words that the students can use when they are writing tourism blogs.
\end{abstract}

Keywords: attitude resources, appraisal language, blog, writing

\section{Introduction}

Writing tourism blogs is one of the important skills that need to be mastered by students majoring in English for tourism course. Through writing tourism blogs, students learn to create various kinds of texts, which suit their target audience. In this context of the study, the purpose of writing tourism blogs is to promote tourist destinations in Bali, Indonesia. By so doing, potential readers can have information about the sites and are interested to visit the tourism spots written in the blogs.

Following Fahreza (2016) and Walker (2007), blog is defined as a virtual informal environment where the students can record their thoughts, opinions, and experiences through texts chronologically based on the topic given by the instructor that is, promoting tourist attractions. Thus, it is obvious that the purpose of writing tourism blogs is to provide readers with a vivid description of the place. In so doing, the readers can visualize the place and are attracted to visit the place. To achieve this purpose, the students should select appropriate linguistic features that can help them achieve their determined communicative purpose (Richardson, 2010)

One of the distinctive language features that can be used in tourism blogs is attitude resources. Developed from the interpersonal metafunction in the framework of Systemic Functional Linguistics (SFL), attitude is a subsystem of Appraisal framework, which can be used by the writers to express their emotions or feelings. (Martin \& White, 2005) divide attitude into three sub-categories: affect, judgement, and appreciation. Affect refers to language resources used to express the writers' emotional reactions. Judgement consists of 
registers used to evaluate people's behavior. Appreciation deals with the evaluation of phenomena or things. In general, attitude can be expressed implicitly (invoked) or explicitly (inscribed) as positive or negative.

Miller et al. (2014) argue that these language resources are significant to be applied in a promotional text, including tourism blog because these resources allow the writers to produce sound arguments (Fitriati \& Solihah, 2019), in which they can build their stance and show their point of view in relation to the promoted issue. In addition to this argument, Ngo \& Unsworth (2015) also emphasize that attitude resources can be used as a catalyst to build a particular kind of relationship with the readers by confirming solidarity with their views or by leading or persuading them towards a certain viewpoint.

Even though attitude resources are important to be used in promotional texts, to the best of our knowledge, only a few studies have examined how students use attitude resources in such texts. The previous studies predominantly focused on investigating the use of attitude resources in students' argumentative texts (e.g., Fauziah et al., 2019; Jalilifar \& Hemmati, 2013; Ngongo, 2017; Solihah, 2020; Yang, 2016; Xinghua \& Thompson, 2009) and in narrative texts (e.g., Fitriati et al., 2018). Studies concerning the use of attitude resources are widely conducted to examine how professional bloggers make use of these resources (e.g., Mocini, 2013; Ho \& Suen, 2017; Wijaya et al., 2019; Wu, 2013). There is a study examining how students use attitude resources in a promotional text conducted by Marsakawati et al. (2019) however, the focus was on spoken business presentation. Thus, to fill in this empirical gap, we conducted a study by focusing on studying how students use attitude resources in tourism blogs. This is beneficial to conduct as this study could provide a balanced investigation about the use of attitude resources in promotional texts. Thus, the results could contribute to English language teaching.

\section{Literature Review}

\subsection{Attitude Resources}

Attitude is one of the subdivisions in Appraisal Language theory proposed by (Martin \& White, 2005). It is a system used to communicate the writers' interpersonal feelings, including the writers' emotions, opinions about other people's behaviours, and evaluation of things. Rooted from systemic functional linguistics, attitude is divided into three domains: affect, judgement, and appreciation.

Affect refers to the writers' emotional reactions. This can be their positive and negative feelings in terms of inclination, happiness, security, and satisfaction. The inclination relates to the expression of the writers' desire toward the certain phenomenon. The resources used can be in the form of verb, such as hope, want, and miss. Happiness consists of the expressions of being happy or sad. This can be shown by using some adjectives, such as happy, sad, cheerful, and gloomy. Security includes the feelings of peace and anxiety such as confident, comfortable, frightened, and uneasy. Satisfaction refers to feelings of achievement and frustration concerning activities that the writers are engaged, for example enjoy, busy, bored, and impressed (Martin \& White, 2005)

Judgement refers to the writers' evaluation of people's behavior in terms of social esteem and social sanction. These are used to admire or criticize, praise or condemn (Fitriati et al., 2018). Referring to Martin \& White (2005), judgement includes four subdivisions: normality (how unusual/special someone is, e.g., lucky, fortunate, and unlucky); capacity (how capable someone is, e.g., clever, humorous, and gifted); tenacity (how dependable someone does something, e.g., brave, heroic, and timid); veracity (how truthful someone's 
behavior is, e.g., honest, tactful, and lying); and propriety (how ethical someone is something, e.g., sensitive, humble, and rude (Martin \& White, 2005)

Appreciation deals with appreciating items used to evaluate things, including humanmade objects, performances, and natural phenomena. This is divided into three subsystems: reaction, composition, and valuation. Reaction refers to resources used to evaluate how things affect the writers such as good, bad, and exciting. Composition deals with registers used to appreciate the balance and the complexity of things, e.g., simple, pure, and elegant. Valuation is used to express the writers' feelings about the value of the things, for example authentic, real, and genuine (Martin \& White, 2005).

\subsection{Empirical review}

Studies concerning the use of attitude resources in students' writing have been conducted by many scholars. In 2013, Jallilifar and Hemmawati investigated how students used appraisal resources in argumentative writing. They collected 15 essays and analyzed them by following the framework of the appraisal theory. Their results found that attitudinal resources were predominantly used by the students. They were used to position readers and clarify the ethical message to readers. Yang (2016) also investigated the use of appraisal resources in students' argumentative writing. Different from the study conducted by Jalilifar \& Hemmati (2013), Yang's study aims at comparing how Chinese and American students used appraisal resources in their writing. By collecting 64 students' essays and analyzed them with the help of the UAM corpus tool, he found that American students used more various and richer appraisal resources than Chinese students.

Besides investigating attitude resources in argumentative texts, studies concerning the use of attitude resources were also conducted to examine students' narrative writing. In 2018, Fitriati, Solihah, and Tusino investigated the use of attitude resources in students' narrative writing. They selected five students' writing, whose topics are Indonesian Folklore. Having analyzed data, they found that among the three subtypes of attitude, affect resources were used more frequently by the students in their writing. Affect resources were used to express the characters' emotions and to involve the readers with the text.

In 2020, Solihah studied the use of attitude resources in students' argumentative writing. Different from the research conducted by Yang (2016), Solihah intended to differentiate how male and female students used attitude resources to build their arguments. Her results showed that either male or female students used a similar distribution of affect resources in their arguments. These resources were used to express their feelings toward the issue given. Even so, her study also revealed that male and female students had different favor in using judgment and appreciation resources.

The review of these studies shows that most studies on appraisal resources were conducted to examine a sole genre in students' writing. To the best of our knowledge, little research has been conducted to investigate how appraisal resources, particularly attitude resources are used in a hybrid genre, such as a blog. We believe that studies in this area are needed to generate practical pedagogical implications to promote the use of attitude resources in such a genre.

\section{Research Method}

The study aims at reporting how attitude resources are realized by the students in their tourism blogs. To achieve this purpose of the study, we used qualitative approach. This approach was chosen because it allows us to collect authentic data in a real field (Creswell, 
Resources of Attitudes in Students' Tourism Blogs, Ni Putu Era Marsakawati, Rima Andriani Sari, Putu Dewi Merlyna Yuda Pramesti, Komang Windi Wahana Putra

2007). In the process of collecting data, we avoid manipulating data. We gathered data, which were naturally available from our source of data: the students' tourism blogs. In line with the purpose of the study, among some forms of qualitative inquiries, we selected discourse analysis of written text as our research design. This is because discourse analysis provides ways for us to study the organization of language above the sentence or clause (Widdowson, 2004). Thus, by following this method of inquiry, we could investigate written texts, including tourism blogs produced by the students.

We selected ten tourism blogs written by ten seventh-semester students majoring in English Language Education. These students took English for Tourism Course in the odd semester of 2020/2021 academic year. The ten tourism blogs were purposively chosen as our object of the study since they are about tourist destinations in Bali, namely Kintamani natural scenery, Lovina Beach, Angsoka Sunflowers Garden, Gili Putih Sumberkima, Menjangan Island, Blue Lagoon Ambengan, Kedu, Kanto Lampo Waterfall,Pantai Teluk Karang Sewu, and Bukit Belong. Additionally, these texts also provided us with sufficient data. To analyze data, we followed Appraisal Language theory of Martin and White (2005). Some steps were taken to analyze data: a) identifying the clause, b) classifying the appraising items into three categories, namely affect, judgment, and appreciation, c) interpreting data, and d) concluding.

\section{Results and Discussion}

The research findings revealed that two attitude resources namely appreciation and affect are applied in the students' tourism blogs. Each of which is presented in the following sections.

\subsection{Appreciation}

Data analysis shows that appreciation resources are predominantly used by the students in their tourism blogs. As stated by Martin \& White (2005), resources of appreciation in the Appraisal Language theory are registers used to express feelings about things or phenomena. Lexicogrammatically, they are expressed by the use of adjectives, as shown in the following tables.

Table 1 Clauses Contained Appreciation Resources in Text 1

\begin{tabular}{llll}
\hline No & Clause & Source & Appraised \\
\hline 1 & (it) has an amazing view & Text1, Clause 2 & View in Kintamani \\
\hline 2 & $\begin{array}{l}\text { Kintamani provides a very unique } \\
\text { and amazing natural scenery }\end{array}$ & Text1, Clause 5 & Natural Scenery \\
\hline 3 & $\begin{array}{l}\text { (it is) surrounded surrounded by } \\
\text { beautiful and lively green nature }\end{array}$ & Text 1, Clause 6 & Nature of Kintamani \\
\hline 4 & $\begin{array}{l}\text { This location is the most strategic } \\
\text { place Text 1, Clause 8 }\end{array}$ & $\begin{array}{l}\text { The location to } \\
\text { reach Kintamani }\end{array}$ \\
\hline 5 & $\begin{array}{l}\text { The air in the Kintamani } \\
\text { environment is very fresh }\end{array}$ & Text1, Clause 13 & The air of Kintamani \\
\hline
\end{tabular}

Table 1 shows lexical items used by student 1 in her tourism blog. She writes about Kintamani, as one of the tourist attractions located in Bangli regency. In promoting the site, she uses quite various lexical items, such as amazing, unique, beautiful, lively, strategic, and 
fresh. These adjectives are purposively selected to evaluate not only Kintamani in general but also details of Kintamani, including the location.

Table 2 Clauses Contained Appreciation Resources in Text 2

\begin{tabular}{llll}
\hline No & Clause & Source & Appraised \\
\hline 1 & $\begin{array}{l}\text { Lovina Beach is one of the most } \\
\text { famous tourist attractions in Bali }\end{array}$ & Text 2, Clause 1 & Lovina \\
\hline 2 & $\begin{array}{l}\text { The waves on Lovina Beach are } \\
\text { quite calm }\end{array}$ & Text2, Clause 13 & Lovina's waves \\
\hline 3 & $\begin{array}{l}\text { This beach is safe for visitors who } \\
\text { want to swim }\end{array}$ & Text 2, Clause 14 & Lovina beach \\
\hline 4 & $\begin{array}{l}\text { Lovina Beach is also known to have } \\
\text { various coral reefs and colorful fish }\end{array}$ & Coral reefs and \\
\hline 5 & $\begin{array}{l}\text { Lovina beach will offer a beautiful } \\
\text { panoramic sunrise. }\end{array}$ & Text2, Clause 20 & Sunrise \\
\hline 6 & $\begin{array}{l}\text { When the sun rises, this Lovina } \\
\text { beach will look exotic with black } \\
\text { sand }\end{array}$ & $\begin{array}{l}\text { Text2, Clause 22 } \\
\text { This activity will be even more } \\
\text { exciting if you do it while reading } \\
\text { a book }\end{array}$ & An activity done at \\
\hline 7
\end{tabular}

Table 2 presents the way student 2 uses appreciation resources in her tourism blog. As she aims to promote Lovina Beach, she uses some registers such as "famous" to emphasize that Lovina is a well-known tourism object. She further provides details why this place becomes famous by describing the beauty of it. Additionally, she also adds activities, which the visitors can do while they are in Lovina Beach. To provoke the readers' interest to come, she uses some lexical items as shown in Table 2.

Table 3 Clauses Contained Appreciation Resources in Text 3

\begin{tabular}{llll}
\hline No & Clause & Source & Appraised \\
\hline 1 & $\begin{array}{l}\text { It is a nice, unique, and interesting } \\
\text { tourist spot }\end{array}$ & Text 3, Clause 6 & $\begin{array}{l}\text { Angsoka } \\
\text { Sunflowers } \\
\text { Garden }\end{array}$ \\
\hline 2 & $\begin{array}{l}\text { It has hundreds of beautiful } \\
\text { sunflowers. }\end{array}$ & Text 3, Clause 11 & Sunflower \\
\hline 3 & ....and easy to reach & Text 3, Clause 15 & The location \\
\hline 4 & $\begin{array}{l}\text { Angsoka Sunflower Garden does } \\
\text { provide a special alternative } \\
\text { vacation destination. Text 3, Clause 16 }\end{array}$ & $\begin{array}{l}\text { Angsoka } \\
\text { Sunflowers } \\
\text { Garden }\end{array}$ \\
\hline 5 & $\begin{array}{l}\text { The scenery is cool and very pretty } \\
\end{array}$ & Text 3, Clause 18 & $\begin{array}{l}\text { Angsoka } \\
\text { Sunflowers } \\
\text { Garden }\end{array}$ \\
\hline 6 & $\begin{array}{l}\text { There are many interesting photo } \\
\text { spots with beautiful sunflowers }\end{array}$ & Text 3, Clause 21 & $\begin{array}{l}\text { Photo } \\
\text { sunflowers }\end{array}$ \\
\hline
\end{tabular}


Resources of Attitudes in Students' Tourism Blogs, Ni Putu Era Marsakawati, Rima Andriani Sari, Putu Dewi Merlyna Yuda Pramesti, Komang Windi Wahana Putra

\begin{tabular}{llll}
\hline $\begin{array}{l}\text { The Angsoka Sunflowers Garden Text 3, Clause 26 } \\
\text { has a very wide area }\end{array}$ & $\begin{array}{l}\text { Area of Angsoka } \\
\text { Sunflowers } \\
\text { Garden }\end{array}$ \\
\hline
\end{tabular}

Table 3 provides examples of clauses containing appreciation resources used by student 3 in her tourism blog. Unlike student 1 and student 2 who write about famous tourism objects in Bali, student 3 introduces and promotes a relatively new tourist spot, in Singaraja, that is Angsoka Sunflowers Garden. Instead of using the word "famous", she begins her writing by stating that the place is nice, unique, and interesting. Besides describing the beauty of the place by using the selected registers presented in Table 3, she also evaluates the way to reach the place by using the lexical item "easy". As the place is a new tourism object, which not many people have visited it, the word "easy" is meaningful to use to give the readers a view that the place is well accessed.

Table 4 Clauses Contained Appreciation Resources in Text 4

\begin{tabular}{|c|c|c|c|}
\hline No & Clause & Source & Appraised \\
\hline 1 & $\begin{array}{l}\text { I said that Buleleng Regency is a } \\
\text { hidden treasure in Bali? }\end{array}$ & Text 4, Clause 5 & Buleleng regency \\
\hline 2 & $\begin{array}{l}\text { Besides having many beautiful } \\
\text { waterfalls with fresh air that } \\
\text { soothes the body and soul, }\end{array}$ & Text 4, Clause 6 & Waterfalls, air \\
\hline 3 & $\begin{array}{l}\text { Buleleng is also famous for its } \\
\text { beaches }\end{array}$ & Text 4, Clause 7 & Buleleng \\
\hline 4 & which have magnificent views & Text 4, Clause 7 & Views of Buleleng \\
\hline 5 & $\begin{array}{l}\text { Lovina beach indeed offers a } \\
\text { breathtaking view of dolphins } \\
\text { dancing }\end{array}$ & Text 4, Clause 11 & $\begin{array}{l}\text { The dancing of } \\
\text { dolpins in Lovina } \\
\text { beach }\end{array}$ \\
\hline 6 & $\begin{array}{l}\text { This beach has a nickname of the } \\
\text { hidden pearl beach in Buleleng }\end{array}$ & Text 4, Clause 13 & The beach \\
\hline 7 & $\begin{array}{l}\text {...this beach feels like a private } \\
\text { beach }\end{array}$ & Text & The beach \\
\hline 8 & $\begin{array}{l}\text { The seawater surrounds this beach } \\
\text { is as clear as crystals }\end{array}$ & Text 4, Clause 36 & The seawater \\
\hline 9 & $\begin{array}{l}\text { Besides photogenic and } \\
\text { instagramable pictures, you can } \\
\text { enjoy the underwater ecosystem }\end{array}$ & Text 4, Clause 37 & $\begin{array}{l}\text { Pictures in the } \\
\text { beach }\end{array}$ \\
\hline 10 & $\begin{array}{l}\text { You are spending your time to see } \\
\text { the sunset from this beach also a } \\
\text { perfect thing to do. }\end{array}$ & Text 4, Clause 39 & $\begin{array}{l}\text { The activity done } \\
\text { in the beach: } \\
\text { enjoying the } \\
\text { sunset }\end{array}$ \\
\hline 11 & $\begin{array}{l}\text { I believe you will never forget the } \\
\text { beautiful view if you visit this } \\
\text { beach. }\end{array}$ & Text 4 , Clause 40 & The beach view \\
\hline
\end{tabular}

Table 4 provides clauses used by student 4 in her tourism blog. Similar to student 3 , student 4 also promotes a tourism spot that has not been widely known by people. This is 
shown by using the word "hidden". She also uses the word "private" to evaluate the beach. Besides, she uses some appraising items as shown in Table 4 to evaluate the view, the scenery, and the activity done by the visitors.

Table 5 Clauses Contained Appreciation Resources in Text 5

\begin{tabular}{|c|c|c|c|}
\hline No & Clause & Source & Appraised \\
\hline 1 & Menjangan island is popular & Text 5, Clause 7 & Menjangan island \\
\hline 2 & $\begin{array}{l}\text { because of its fantastic } \\
\text { underwater gardens }\end{array}$ & Text 5, Clause 8 & $\begin{array}{l}\text { The Underwater } \\
\text { gardens of the } \\
\text { Menjangan island }\end{array}$ \\
\hline 3 & $\begin{array}{l}\text { When they can see the beauty of } \\
\text { the underwater natural paintings } \\
\text { of this island. }\end{array}$ & Text 5, Clause 10 & $\begin{array}{l}\text { The underwater } \\
\text { paintings, }\end{array}$ \\
\hline 4 & The waters are also perfect & Text 5, Clause 14 & The waters \\
\hline 5 & because it is calm and super clean & Text 5, Clause 15 & The waters \\
\hline 6 & $\begin{array}{l}\text {.....to discover various corals, } \\
\text { plants, and fish, such as tuna, } \\
\text { batfish, sea turtles, angelfish, } \\
\text { jackfish, and many more }\end{array}$ & Text 5, Clause 16 & $\begin{array}{l}\text { Corals, plants, and } \\
\text { fish }\end{array}$ \\
\hline 7 & $\begin{array}{l}\text { whose color is very beautiful with } \\
\text { the twisting movements like } \boldsymbol{a} \\
\text { dancer }\end{array}$ & Text 5, Clause 18 & Mandarine fish \\
\hline 8 & $\begin{array}{l}\text { This wonderful panorama becomes } \\
\text { a snorkeling and diving spot }\end{array}$ & Text 5, Clause 19 & $\begin{array}{l}\text { Panorama of the } \\
\text { beach }\end{array}$ \\
\hline 9 & $\begin{array}{l}\text {..there are also } 8 \text { ancient sacred } \\
\text { temples on this island }\end{array}$ & Text 5, Clause 21 & $\begin{array}{l}\text { Temples in } \\
\text { Menjangan island }\end{array}$ \\
\hline 10 & $\begin{array}{l}\text { because the atmosphere on the } \\
\text { island is still relatively calm }\end{array}$ & Text 5, Clause 28 & The atmosphere \\
\hline 11 & $\begin{array}{l}\text { This price is still relatively } \\
\text { affordable }\end{array}$ & Text 5, Clause 37 & The price \\
\hline 12 & to visit a wonderful island & Text 5, Clause 38 & $\begin{array}{l}\text { The menjangan } \\
\text { island }\end{array}$ \\
\hline
\end{tabular}

In Table 5, some examples of appreciation resources used by student 5 are presented. The registers are quite varied and rich to provide a beautiful picture of the place. Besides, an appraising item such as affordable is used to invite the readers to come to the place. She also gives her final evaluation by using "wonderful" to refer to the place.

Table 6 Clauses Contained Appreciation Resources in Text 6

\begin{tabular}{llll}
\hline No & Clause & Source & Appraised \\
\hline 1 & $\begin{array}{l}\text {...which famous with the beautiful } \\
\text { Waterfalls }\end{array}$ & Text 6 Clause 4 & Ambengan village \\
\hline 2 & $\begin{array}{l}\text { f...because the beautiful blue } \\
\text { water }\end{array}$ & $\begin{array}{l}\text { Text 6 Clause } 7 \\
\text { Blue Lagoon also easy to find on Text 6 Clause } 8\end{array}$ & $\begin{array}{l}\text { The water of the } \\
\text { blue lagoon }\end{array}$ \\
\hline 3 & $\begin{array}{l}\text { The location of } \\
\text { blue lagoon }\end{array}$ \\
\hline
\end{tabular}


Resources of Attitudes in Students' Tourism Blogs, Ni Putu Era Marsakawati, Rima Andriani Sari, Putu Dewi Merlyna Yuda Pramesti, Komang Windi Wahana Putra

\begin{tabular}{|c|c|c|c|}
\hline 4 & $\begin{array}{l}\text {...the entrance ticket is really cheap } \\
\text { for both local and foreign tourist }\end{array}$ & Text 6 Clause 9 & entrance \\
\hline 5 & $\begin{array}{l}\text { The water of Blue Lagoon come } \\
\text { from the mountainous area }\end{array}$ & Text 6 Clause 10 & $\begin{array}{l}\text { The area around } \\
\text { the blue lagoon }\end{array}$ \\
\hline 6 & $\begin{array}{l}\text { and create a natural pool with a } \\
\text { beautiful blue-colored water }\end{array}$ & Text 6 Clause 12 & $\begin{array}{l}\text { The pool, the } \\
\text { water }\end{array}$ \\
\hline 7 & $\begin{array}{l}\text { Blue Lagoon offers a bit } \\
\text { adventurous track }\end{array}$ & Text 6 Clause 13 & The track \\
\hline 8 & ....and pass big river stones & Text 6 Clause 16 & The river stones \\
\hline 9 & For sure it is a bit tiring & Text 6 Clause 17 & $\begin{array}{l}\text { The journey to } \\
\text { reach the place } \\
\text { (blue lagoon) }\end{array}$ \\
\hline 10 & because the water is so fresh & Text 6 Clause 22 & The water \\
\hline 11 & and it is really safe & Text 6 Clause 23 & The pool \\
\hline 12 & It is a private pool & Text 6 Clause 27 & The pool \\
\hline 13 & $\begin{array}{l}\text { it is located on top of the of the } \\
\text { Holy Aling Aling Waterfall }\end{array}$ & Text 6 Clause 32 & $\begin{array}{l}\text { The Aling-Aling } \\
\text { waterfall }\end{array}$ \\
\hline
\end{tabular}

Table 7 Clauses Contained Appreciation Resources in Text 7

\begin{tabular}{|c|c|c|c|}
\hline No & Clause & Source & Appraised \\
\hline 1 & $\begin{array}{l}\text { There is a hidden destination at } \\
\text { Panji Village named Kedu } \\
\text { (refreshing water destination). }\end{array}$ & Text 7 Clause 1 & Kedu \\
\hline 2 & It is popular & Text 7 Clause 6 & Kedu \\
\hline 3 & $\begin{array}{l}\text { because it offers you with a fresh } \\
\text { vibes and water }\end{array}$ & Text 7 Clause 7 & Vibes and water \\
\hline 4 & it is actually easy & Text 7 Clause 8 & $\begin{array}{l}\text { The access to } \\
\text { reach the location }\end{array}$ \\
\hline 5 & $\begin{array}{l}\text { The water of Kedu comes from the } \\
\text { mountainous area }\end{array}$ & Text 7 Clause 11 & $\begin{array}{l}\text { The area, where } \\
\text { the water comes }\end{array}$ \\
\hline 6 & $\begin{array}{l}\text { And becomes a refreshing water } \\
\text { destination }\end{array}$ & Text 7 Clause 13 & Water destination \\
\hline 7 & $\begin{array}{l}\text { This place could make you more } \\
\text { relaxed }\end{array}$ & Text 7 Clause 14 & The place (Kedu) \\
\hline 8 & The water is very safe for children & Text 7 Clause 18 & The water \\
\hline 9 & Visiting this place is quite difficult & Text 7 Clause 20 & To visit the place \\
\hline 10 & $\begin{array}{l}\text { because the terrain is rocky } \\
\text { enough }\end{array}$ & Text 7 Clause 21 & The terrain \\
\hline
\end{tabular}

Tables 6 and 7 present examples of lexical items used by students 6 and 7 to promote waterfalls. The appraising items used by them are dominantly used to evaluate the water. Besides, the information about how to reach the site and how much money to pay are presented by adding effective registers. In blogs, they also use negative appreciation resources, such as tiring, difficult, and rocky. Even though these registers are negative, they show a genuine description of the place. These are used to provide a caution for the prospective visitors. Thus, the visitors can prepare themselves if they want to visit the place. 
Table 8 Clauses Contained Appreciation Resources in Text 8

\begin{tabular}{|c|c|c|c|}
\hline No & Clause & Source & Appraised \\
\hline 1 & $\begin{array}{l}\text { Are you looking for a natural } \\
\text { waterfall? }\end{array}$ & Text 8 Clause 1 & The waterfall \\
\hline 2 & $\begin{array}{l}\text { Kanto Lampo waterfall may not be } \\
\text { one of the well-known waterfalls } \\
\text { in Bali }\end{array}$ & Text 8 Clause 3 & $\begin{array}{ll}\text { Kanto Lampo } \\
\text { waterfall }\end{array}$ \\
\hline 3 & $\begin{array}{l}\text { Kanto Lampo still a perfect natural } \\
\text { scenery }\end{array}$ & Text 8 Clause 4 & The scenery \\
\hline 4 & $\begin{array}{l}\text { Kanto Lampo waterfall is a hidden } \\
\text { waterfall }\end{array}$ & Text 8 Clause 7 & The waterfall \\
\hline 5 & $\begin{array}{l}\text { It is because this waterfall has } \\
\text { unique characteristics }\end{array}$ & Text 8 Clause 11 & The waterfall \\
\hline 6 & $\begin{array}{l}\text { The rock arrangement on the cliff is } \\
\text { quite artistic }\end{array}$ & Text 8 Clause 16 & $\begin{array}{l}\text { The cliffs around } \\
\text { the waterfall }\end{array}$ \\
\hline 7 & $\begin{array}{l}\text { while taking a shower, enjoying the } \\
\text { fresh and clear of Kanto Lampo } \\
\text { waterfal }\end{array}$ & Text 8 Clause 19 & $\begin{array}{ll}\text { Kanto Lampo } \\
\text { waterfall }\end{array}$ \\
\hline 8 & $\begin{array}{l}\text { This is categorized as a cheap } \\
\text { tourist destination }\end{array}$ & Text 8 Clause 22 & $\begin{array}{l}\text { The price of the } \\
\text { destination }\end{array}$ \\
\hline 9 & $\begin{array}{l}\text { Are you the next person to visit } \\
\text { this beautiful waterfall? }\end{array}$ & Text 8 Clause 24 & Waterfall \\
\hline
\end{tabular}

Table 8 presents lexical items used by student 8 to promote Kanto Lampo waterfall. The registers are selected to picture the beauty of the place. Even, she uses the word "artistic" to describe the cliff. This is used to build the visitors' beautiful imagination about the place. The register "cheap" is used to attract visitors to come to the place.

Table 9 Clauses Contained Appreciation Resources in Text 9

\begin{tabular}{|c|c|c|c|}
\hline No & Clause & Source & Appraised \\
\hline 1 & $\begin{array}{l}\text { One of the wonderful natural } \\
\text { attractions is Pantai Teluk Karang } \\
\text { Sewu Jembrana, Bali }\end{array}$ & Text 9 Clause 10 & $\begin{array}{l}\text { Pantai Teluk } \\
\text { Karang Sewu }\end{array}$ \\
\hline 2 & $\begin{array}{l}\text { Pantai Teluk Karang Sewu is one of } \\
\text { the popular tourist attractions in } \\
\text { Jembrana, Bali. }\end{array}$ & Text 9 Clause 11 & $\begin{array}{l}\text { Pantai Teluk } \\
\text { Karang Sewu }\end{array}$ \\
\hline 3 & Karang Sewu is famous & Text 9 Clause 15 & $\begin{array}{l}\text { Pantai Teluk } \\
\text { Karang Sewu }\end{array}$ \\
\hline 4 & There is a unique bridge & Text 9 Clause 17 & The bridge \\
\hline 5 & $\begin{array}{l}\text {..and it becomes a photo spot for } \\
\text { the guest with a mountain and } \\
\text { wide sea background }\end{array}$ & Text 9 Clause 20 & $\begin{array}{l}\text { The sea for } \\
\text { background photo }\end{array}$ \\
\hline 6 & .....which makes it very popular & Text 9 Clause 22 & $\begin{array}{l}\text { The uniqueness of } \\
\text { the beach }\end{array}$ \\
\hline 7 & What a very amazing place for a & Text 9 Clause 32 & Pantai \\
\hline
\end{tabular}


Resources of Attitudes in Students' Tourism Blogs, Ni Putu Era Marsakawati, Rima Andriani Sari, Putu Dewi Merlyna Yuda Pramesti, Komang Windi Wahana Putra

\begin{tabular}{llll}
\hline & holiday & Karang Sewu \\
\hline 8 & $\begin{array}{l}\text { the location of Karang Sewu also Text 9 Clause 33 } \\
\text { very strategic }\end{array}$ & $\begin{array}{l}\text { The location of } \\
\text { Karang Sewu }\end{array}$ \\
\hline 9 & $\begin{array}{l}\text { It closes with famous food in Text 9 Clause 33 } \\
\text { Jembrana }\end{array}$ & Restaurant \\
\hline 10 & $\begin{array}{l}\text { It can make the holiday more } \\
\text { complete and perfect }\end{array}$ & Text 9 Clause 34 holiday \\
\hline 11 & $\begin{array}{l}\text { To enter into Karang Sewu the fee } \\
\text { is really cheap }\end{array}$ & Text 9 Clause 38 \\
\hline 12 & $\begin{array}{l}\text { Karang Sewu can complete our } \\
\text { holiday with amazing nature }\end{array}$ & Text 9 Clause 42 \\
\hline
\end{tabular}

Table 9 shows registers used by student 9 to describe Pantai Teluk Karang Sewu. As he writes in his blog, the place is not new. Many people have visited the place, that's why he used the lexical items, such as popular and famous. Even so, he still needs to promote it by evaluating the view, the location, and the restaurant near the place by using appraising items as stated in Table 9.

Table 10 Clauses Contained Appreciation Resources in Text 10

\begin{tabular}{|c|c|c|c|}
\hline No & Clause & Source & Appraised \\
\hline 1 & $\begin{array}{l}\text { Bukit Belong offers light trekking } \\
\text { to the visitors }\end{array}$ & Text 10 Clause 4 & Bukit Belong \\
\hline 2 & $\begin{array}{l}\text { Bukit Belong is a very wide green } \\
\text { hill }\end{array}$ & Text 10 Clause 8 & Hill \\
\hline 3 & The trees grow very fertile & Text 10 Clause 9 & The tress \\
\hline 4 & $\begin{array}{l}\ldots \text { visitors can also see very green } \\
\text { rice fields and the local houses }\end{array}$ & Text 10 Clause 14 & The rice fields \\
\hline 5 & The view from this hill is wonderful & Text 10 Clause 15 & The view \\
\hline 6 & $\begin{array}{l}\text { The iconic part of Bukit Belong is a } \\
\text { dead tree trunk }\end{array}$ & Text 10 Clause 16 & The dead tree \\
\hline 7 & $\begin{array}{l}\text { This is because the tree becomes a } \\
\text { very aesthetic and attractive } \\
\text { photo spot }\end{array}$ & Text 10 Clause 17 & The dead tree \\
\hline
\end{tabular}

Table 10 shows some examples of appreciation resources used by student 10 in her tourism blog. They are all selected to build a positive image of the place so that the visitors are attracted to come to the place. Student 10 does not only describe the view and the scenery but also offers the prospective visitors the activity, which they might enjoy while they are in Bukit Belong.

\subsection{Affect}

Data analysis shows that students use some affect resources in their blogs. The examples of affect resources are presented in Table 11.

Table 11 Examples of Clauses Contained Affect Resources

\begin{tabular}{lllll}
\hline No & Clause & & Source & Appraised \\
\hline 1 & The visitors can also enjoy a & Text 1 Clause 15 & Hot spring bath \\
\hline
\end{tabular}




\begin{tabular}{|c|c|c|c|}
\hline & $\begin{array}{l}\text { natural hot spring bath in Toya } \\
\text { Bungkah Village }\end{array}$ & & \\
\hline 2 & $\begin{array}{l}\text { The tourists do not need to worry } \\
\text { to think about which season is the } \\
\text { best for a visit }\end{array}$ & Text 3 Clause 29 & $\begin{array}{l}\text { Season to visit the } \\
\text { place }\end{array}$ \\
\hline 3 & $\begin{array}{l}\text { Tourists can enjoy the beauty of } \\
\text { sunflowers }\end{array}$ & Text 3 clause 30 & $\begin{array}{l}\text { The beauty of } \\
\text { sunflowers }\end{array}$ \\
\hline 4 & $\begin{array}{l}\text { You can enjoy the underwater } \\
\text { ecosystem. }\end{array}$ & Text 4 Clause 37 & $\begin{array}{l}\text { The underwater } \\
\text { ecosystem }\end{array}$ \\
\hline 5 & $\begin{array}{l}\text { Menjangan island area always } \\
\text { impress the visitors }\end{array}$ & Text 5 Clause 12 & Menjangan island \\
\hline 6 & $\begin{array}{l}\text { People are also attracted to come } \\
\text { to Menjangan island }\end{array}$ & Text 5 Clause 27 & Menjangan island \\
\hline 7 & $\begin{array}{l}\text { the scenery will amaze your eyes } \\
\text { and }\end{array}$ & Text 6 Clause 19 & $\begin{array}{l}\text { The scenery in } \\
\text { Blue Lagoon } \\
\text { Ambengan }\end{array}$ \\
\hline 8 & ... and relax your soul & Text 6 Clause 20 & $\begin{array}{l}\text { The scenery in } \\
\text { Blue Lagoon } \\
\text { Ambengan }\end{array}$ \\
\hline 9 & This place will refresh your day & Text 7 Clause 26 & Kedu \\
\hline 10 & $\begin{array}{l}\text {...and make you feel happy to do } \\
\text { anything }\end{array}$ & Text 7 Clause 27 & Kedu \\
\hline 11 & $\begin{array}{l}\text {....which make the guest more } \\
\text { comfortable lay on the grass }\end{array}$ & Text 9 Clause 31 & Karang Sewu \\
\hline
\end{tabular}

Table 11 provides examples of clauses containing affect resources. The registers such as enjoy, worry, relax, comfortable, impress, attract, amaze, refresh, and happy are used to describe the feelings that will be felt by the visitors if they come to the place. These language resources are used to promote the place and to invite readers to visit the place.

Based on data analysis shown in sections 4.1 and 4.2, it is revealed that the students used two out of three attitude resources, namely appreciation and affect. Appreciation is the most dominant language resource used in the students' blogs. Appreciation is realized by appreciating items used to evaluate the phenomenon and details available in the promoted places. Some examples of registers used by the students are fantastic, natural, calm, perfect, clean, various, beautiful, wonderful, fresh, safe, private, relaxed, unique, artistic, clear, wide, amazing, strategic, green, iconic, aesthetic, and attractive. These lexical items are used to make the text sounds more appreciative (Hood, 2004). Affect also appears in the students' blogs. Affect resources are used to express feelings or emotions, which are felt by the visitors if they visit the promoted places. The examples of affect resources can be seen in Table 11.

The use of appreciation and affect resources is purposively selected to achieve the purpose of the text, that is, to promote tourism objects. In promoting the tourism objects, the students need to describe the place clearly and vividly so that the readers can possibly see, smell, and feel the details being described in the texts (Knapp \& Watkins, 2005; Noprianto, 2017). By so doing, the readers can visualize the beauty of the place and are felt attracted to come to the place. To achieve this aim, the students need to consider the use 
of registers. As argued by Mendale et al. (2019) that the use of vocabulary is an important element in creating a text aiming to describe a place. A good selection of vocabulary can enable readers to picture what is being portrayed in the text. Thus, the use of adjectives and verbs (actions) must be used in such text to provide a more detailed description of the topic. Besides, mental verbs are also needed to describe the feelings felt either by the writer or by the readers (Gerot \& Wignell, 1994; Knapp \& Watkins, 2005).

Even though the results of the study indicate that the students can use attitude resources in their blogs, further analysis reveals that the students tend to use basic and repetitive words. In appreciation resources, the word "beautiful" is not only repeated in the same text but is also appeared in all students' texts. Similarly, in affect resources, the lexical item "enjoy" is predominantly and repetitively used by the student. They can vary the words to build a more vivid picture of the text. This indicates that students have limited vocabulary. This research finding is in line with the study conducted by T Ngo et al. (2012). They further argue that this might be caused by the limited exposure of attitude resources given by the teachers. Thus, scaffolding the structure of the text and modeling the linguistic features are highly needed.

\section{Conclusion}

Our research underlined how students used attitude resources in their tourism blogs. The study revealed that two attitude resources, namely appreciation and affect are used by the students in their writing. However, the use of these two resources is still limited as the students used basic and repetitive words. The research findings might benefit language practitioners to provide EFL learners with explicit attitude resources to help them build and achieve the social purpose of the text. This can be done by familiarizing students with authentic materials containing lexical items used to give an account of imagined places.

Further work needs to be carried out to investigate how students with different levels of English proficiency use attitude resources in their blogs. In addition, future studies in the form of comparative study between novice and professional blog writers or between Indonesian and American blog writers are also needed to explore and document both similarities and differences of the writers in using attitude resources in their writing.

\section{ACKNOWLEDGEMENTS}

This work was supported by the research institution and community service of Universitas Pendidikan Ganesha Number: SP DIPA-023.17.2.677530/2021 following the Research Contract Number: 382/UN48.16/LT/2021. We are also thankful for the contribution given by all members in accomplishing the project.

\section{References}

Creswell, J. W. (2007). Qualitative Inquiry \& Research Design: Choosing among Five Approaches. Second edition. London: Sage publications.

Fahreza, M. (2016). The Use of Weblog in Improving Students' Writing Skill. Research in English and Education Journal, 2(3), 17-25.

Fauziah, M., Warsono, \& Widhiyanto. (2019). The Comparison of Appraisal Resources in Argumentative Essays Written by Students with Different Proficiency Levels. English Education Journal, 9(4), 484-491.

Fitriati, S. W., \& Solihah, Y. A. (2019). Non-native Writers and the Use of Appraisal Resources 
in Research Article Introductions. Indonesian Journal of Applied Linguistics, 8(3), 638645.

Gerot, L., \& Wignell, P. (1994). Making Sense of Functional Grammar: An Introductory Workbook. New South Wealth: Gerd Stabler.

Ho, V., \& Suen, A. (2017). Promoting a City's Core Values Using Evaluative Language. International Journal of Applied Linguistics (United Kingdom), 27(1), 286-308.

Hood, S. (2004). Appraisal Research: Taking a Stance in Academic Writing. Unpublished Doctoral Dissertation. University of Technology, Sydney, Sydney.

Jalilifar, A., \& Hemmati, A. (2013). Construction of Evaluative Meanings by Kurdish- Speaking Learners of English: A Comparison of High-and Low-Graded Argumentative Essays. Issues in Language Teaching (ILT), 2(2), 57-84.

Knapp, P., \& Watkins, M. (2005). Genre, Text, Grammar: Technologies for Teaching and Assessing Writing. Sidney: UNSW Press.

Marsakawati, N. P. E., Mujiyanto, J., Agustien, H. I. R., \& Astuti, P. (2019). An Indonesian EFL Learner's Use of Evaluative Language and Gestures in a Spoken Persuasive Presentation: A Case Study. Journal of Asia TEFL, 16(1), 401-410.

Martin, J. R., \& White, P. R. R. (2005). The Language of Evaluation: Appraisal in English. New York: Palgrave Macmillan.

Mendale, B. P., Komariah, E., \& Fitriani, S. S. (2019). Analyzing Students' Ability in Using the Language Features in Writing Descriptive text. Research in English and Education Journal, 4(4), 183-189.

Miller, R. T., Mitchell, T. D., \& Pessoa, S. (2014). Valued Voices: Students' Use of Engagement in Argumentative History Writing. Linguistics and Education, 28, 107-120.

Mocini, R. (2013). The Promotional Functionality of Evaluative Language in Tourism Discourse. Lingue e Linguaggi, 9(1), 157-172.

Ngo, Thu, \& Unsworth, L. (2015). Reworking the Appraisal Framework in ESL Research: Refining Attitude Resources. Functional Linguistics, 2(1), 1-24.

Ngongo, M. (2017). Systemic Analysis of Text Appraisal on students' Theses Writing in English. Journal of Scientific Research and Studies, 4(4), 67-72.

Noprianto, E. (2017). Student's Descriptive Text Writing in SFL Perspectives. IJELTAL (Indonesian Journal of English Language Teaching and Applied Linguistics), 2(1), 6581.

Richardson, W. (2010). Blogs, Wikis, Podcasts, and Other Powerful Web Tools for Classrooms. California: Corwin press.

Walker, J. (2007). Blog. In D. Herman, M. Jahn, \& M. Ryan (Eds.), The Routledge Encyclopedia of Narrative Theory. London: Routledge.

Widdowson, H. G. (2004). Text, Context, Pretext: Critical Issues in Discourse Analysis. Malden: Wiley Blackwell.

Wijaya, L., Hanum, A., Syaharani, N., \& Nst, S. (2019). Appraisal Analysis on Thailand Advertisement. Scientific Journal of Linguistics, Literature, and Education, 8(1), 27-32.

Wu, H. (2013). Appraisal Perspective on Attitudinal Analysis of Public Service Advertising Discourse. English Language and Literature Studies, 3(1),55-66.

Xinghua, L., \& Thompson, P. (2009). Attitude in Students' Argumentative Writing: A Contrastive Perspective. Language Studies Working Papers, 1(1), 3-15.

Yang, Y. (2016). Appraisal Resources in Chinese College Students' English Argumentative Writing. Journal of Language Teaching and Research, 7(5), 1002-1013. 